\title{
Alcohol and the emergency service patient
}

\author{
S HOLT, I C STEWART, J M J DIXON, R A ELTON, T V TAYLOR, K LITTLE
}

\section{Summary and conclusions}

To determine the prevalence of alcohol use in casualty patients breath-alcohol analysis was performed on 702 patients attending the accident and emergency department of a large teaching hospital during the evening. Forty per cent of patients had consumed alcohol before attending and $32 \%$ had a blood alcohol concentration exceeding $17.4 \mathrm{mmol} / 1(80 \mathrm{mg} / 100 \mathrm{ml})$. Clinical assessment of intoxication resulted in a false-negative diagnosis . in $10 \%$ of inebriated patients, indicating that an objective measurement of the blood alcohol concentration by a test, such as breath-alcohol analysis, may be of additional value.

These findings confirm that a high proportion of emergency-service patients are affected by alcohol and suggest that alcoholism treatment facilities need to be integrated with accident and emergency services.

\section{Introduction}

Excessive drinking has become increasingly recognised as a major medical problem, and a significant proportion of patients $(10-40 \%)$ in general hospitals may be problem drinkers. ${ }^{1-3}$ Nevertheless, many patients affected by. alcohol pass unrecognised in both hospital and general practice, and treatment may concentrate on the sequelae of alcoholism without touching the underlying problem. ${ }^{145}$ Aithough many clinicians are aware that patients who attend accident and emergency departments are often affected by alcohol, there have been few attempts to estimate the magnitude of this problem.

The intoxicated patient presents a diagnostic challenge to the casualty officer since the contribution of alcohol to the clinical state of the patient may often be misjudged, particularly in stuporous or unconscious patients. Clinical signs of inebriation are unreliable, and a clinician may consider a patient sober when the blood alcohol concentration indicates severe inebriation. ${ }^{6}$ ? A wrong or delayed diagnosis because of alcoholic intoxication may be especially critical in circumstances such as self-poisoning or trauma, where recovery may depend on early treatment. ${ }^{89}$ The need for a test that will give an immediate estimate of the blood alcohol concentration in such cases ${ }^{7}$ has led to the use of breath-alcohol analysis as a diagnostic tool, but the value of this technique has not been explored in general clinical practice. ${ }^{10} 11$

To estimate the prevalence of alcohol use in casualty patients blood alcohol concentrations were measured by breath-alcohol analysis in 702 patients attending the emergency department of the Royal Infirmary, Edinburgh, during the evening.

\section{Subjects and method}

Data were collected from 702 patients who attended the accident and emergency department of the Royal Infirmary, Edinburgh, on 17

The Royal Infirmary and Medical Computing and Statistics Unit, University of Edinburgh, Edinburgh

$S$ HOLT, MB, MRCP, lecturer and senior registrar (now research fellow, Addiction Research Foundation, Toronto, Ontario M5S 2S1)

I C STEWART, $M B$, CHB, lecturer and senior house officer

J $M$ J DIXON, $M B, C H B$, senior house officer

R A ELTON, BA, PHD, lecturer

$T$ V TAYLOR, MD, FRCS, senior lecturer and consultant surgeon

$\mathrm{K}$ LITTLE, MD, consultant in accident and emergency services different evenings from 2 March to 18 November 1979. These evenings consisted of one Monday, three Wednesdays, three Thursdays, eight Fridays, and two Saturdays. All consecutive attendances between the hours of $5 \mathrm{pm}$ and 9 am were examined. The Royal Infirmary is a 978-bed teaching hospital with all the major medical specialties. It serves as a district general hospital for much of the population of Edinburgh and surrounding areas ( 750000 people), and the accident and emergency department had 59259 attendances from 1 January to 31 December 1979.

For each patient a doctor recorded four specific symptoms and signs (alcoholic foetor, slurred speech, abnormal motor co-ordination, and red conjunctivae) as present or absent and assessed the apparent degree of intoxication (none, mild, moderate, or severe). Each patient was examined by one of two doctors. The level of consciousness was graded as follows: grade 1, conscious and alert; grade 2, drowsy but responsive to command; grade 3 , unconscious but responding to painful stimuli; and grade 4, unconscious and unresponsive. Information on the age, sex, social class, ${ }^{12}$ and principal diagnosis, with special reference to road traffic accidents, assaults, and trauma, was also collected for each. At the end of the interview the examining physician made a subjective comment on the contribution of alcohol to the patient's attendance, and breath-alcohol was measured with a pocket Alcolmeter (Lion Labs, Cardiff)..$^{13}$

The pocket Alcolmeter measures ethanol concentration in a volumetrically trapped breath sample $(1.5 \mathrm{ml})$ by electrochemical oxidation and gives a reading expressed in terms of blood alcohol concentration. End-expiratory sampling was performed through a detachable plastic mouthpiece (or nosepiece for unconscious patients). When the reading was positive the sampling was repeated and an average value from the two readings obtained. Regular calibration checks were made by passing known concentrations of alcohol vapour (NALCO alcohol, vapour standard of alcohol in argon, Lion Labs, Cardiff) through the instrument.

Two patients would not co-operate and information was incomplete. Data from the recording forms were keypunched and stored on a

\section{MINIPRINT}
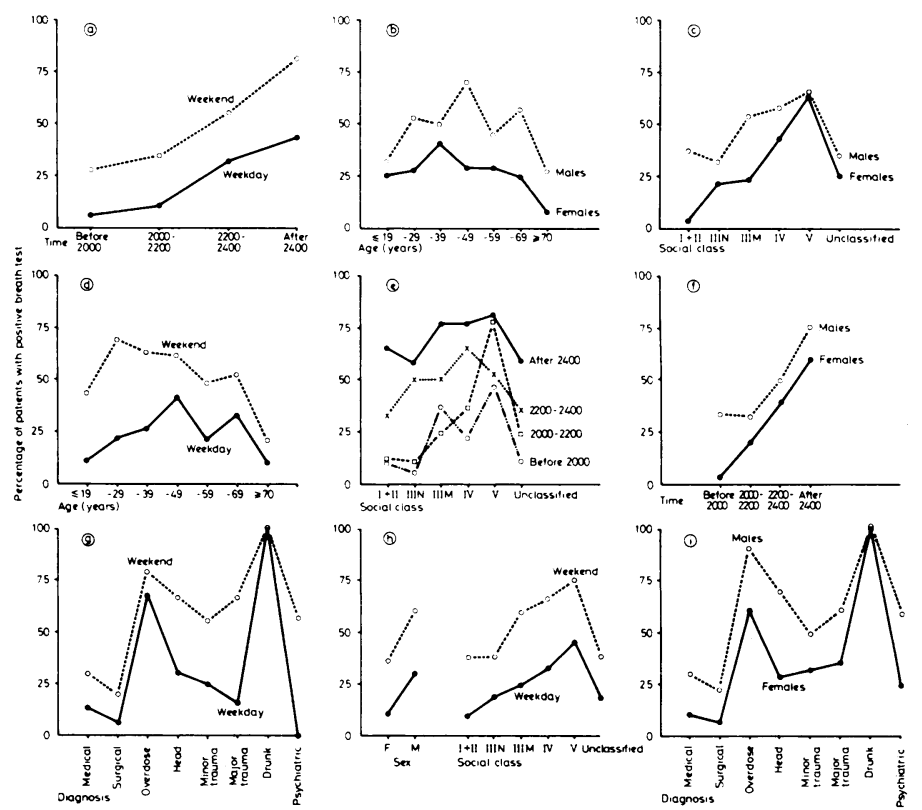

Percentage of positive breath tests in all patients according to $(a)$ time of day on weekdays and weekends; $(b)$ age and sex; $(c)$ social class and sex; $(d)$ age on weekdays and weekends; $(e)$ social class and time of day; $(f)$ sex and time of day; $(g)$ diagnosis on weekdays and weekends; $(h)$ social class on weekdays and weekends; and (i) diagnosis and sex. 
computer file. The prevalence of positive breath tests in relation to various patient characteristics was determined, and the interaction of alcohol consumption with these characteristics was determined by multiple logistic regression. Information was incomplete on a small number of patients for some characteristics such as age.

\section{Results}

Overall $40 \%$ of the patients had positive breath-alcohol readings (table I), and $32 \%$ had a breath-alcohol level exceeding $17.4 \mathrm{mmol} / 1$ $(80 \mathrm{mg} / 100 \mathrm{ml}$; the legal limit for driving a motor vehicle in the United Kingdom). In $24 \%$ of all patients the examining doctor the factors appeared to act more or less independently in determining a positive breath test. For example, the incidence of alcohol use was high at weekends and late in the evening, but the incidence at the weekend was high at each time of study and was not explained purely by a later average time of attendances.

Correlations between breath-alcohol measurements, specific symptoms and signs of intoxication, and assessment of level of consciousness are shown in table II. Almost all the patients who were scored as possessing clinical features of intoxication had positive breath-alcohol tests, but there were false-negative diagnoses in $19 \%$ of patients who had been drinking. Smell on the breath was the most useful criterion, and slurred speech and abnormal co-ordination the least useful. The subjective rating of apparent degree of intoxication performed by the two doctors showed reasonable correlation with

TABLE I-Clinical and biochemical assessment of alcohol use in patients attending accident and emergency department according to social factors and circumstances of attendance

\begin{tabular}{|c|c|c|c|c|c|c|c|c|c|}
\hline \multicolumn{4}{|c|}{ Category } & \multirow[t]{2}{*}{$\begin{array}{c}\text { No of } \\
\text { patients }\end{array}$} & \multicolumn{2}{|c|}{$\begin{array}{c}\text { No }(\%) \text { of patients affected by } \\
\text { alcohol }\end{array}$} & \multirow{2}{*}{$\begin{array}{l}\text { Mean blood alcohol } \\
\text { concentration for } \\
\text { those patients with } \\
\text { positive Alcolmeter } \\
\text { reading (mmol/l) }\end{array}$} & \multicolumn{2}{|c|}{$\begin{array}{l}\text { No (\%) of patients for whom alcohol } \\
\text { was judged to have contributed to } \\
\text { attendance }\end{array}$} \\
\hline & & & & & Positive test & $\geqslant 17.4 \mathrm{mmol} / \mathrm{l}$ & & Directly & Indirectly \\
\hline \multirow{2}{*}{$\begin{array}{l}\text { All cases } \\
\text { Sex: } \\
\text { Men } \\
\text { Women }\end{array}$} & .. & .. & $\cdots$ & 702 & $283(40)$ & $227(32)$ & $36 \cdot 0$ & $166(24)$ & $46(7)$ \\
\hline & 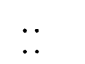 & $\because$ & $\because$ & $\begin{array}{l}442 \\
260\end{array}$ & $\begin{array}{r}214(48) \\
69(27)\end{array}$ & $\begin{array}{r}181(41) \\
46(18)\end{array}$ & $\begin{array}{l}37 \cdot 6 \\
30 \cdot 6\end{array}$ & $\begin{array}{r}130(30) \\
36(14)\end{array}$ & $\begin{array}{l}32(7) \\
14(5)\end{array}$ \\
\hline $\begin{array}{l}\text { Class: } \\
\text { I+II } \\
\text { III N } \\
\text { III } \mathrm{M} \\
\text { IV } . \\
\text { V } \\
\text { Unclassif } \\
\text { Une (vears) }\end{array}$ & $\begin{array}{c}\ldots \\
\cdots \\
\cdots \\
\text { fied }\end{array}$ & $\begin{array}{l}. . \\
\because \\
\because \\
\because\end{array}$ & $\begin{array}{l}\cdots \\
\cdots \\
\cdots \\
\cdots\end{array}$ & $\begin{array}{r}73 \\
79 \\
163 \\
74 \\
88 \\
225\end{array}$ & $\begin{array}{l}20(27) \\
22(28) \\
79(48) \\
39(53) \\
56(64) \\
67(30)\end{array}$ & $\begin{array}{l}14(19) \\
15(19) \\
62(38) \\
35(47) \\
45(51) \\
56(25)\end{array}$ & $\begin{array}{l}31 \cdot 7 \\
30 \cdot 2 \\
33 \cdot 9 \\
38 \cdot 2 \\
38 \cdot 0 \\
38 \cdot 4\end{array}$ & $\begin{array}{l}13(18) \\
11(14) \\
39(24) \\
19(26) \\
41(47) \\
43(19)\end{array}$ & $\begin{array}{c}2(3) \\
4(5) \\
13(8) \\
8(11) \\
4(5) \\
15(7)\end{array}$ \\
\hline $\begin{array}{c}\leqslant 19 \\
20-29 \\
30-39 \\
40-49 \\
50-59 \\
60-69 \\
70+\end{array}$ & $\begin{array}{l}\ldots \\
\ldots \\
\cdots \\
\cdots \\
.\end{array}$ & $\begin{array}{l}\because \\
\because \\
\because \\
\because \\
\therefore\end{array}$ & $\begin{array}{l}\ldots \\
\cdots \\
\cdots \\
\cdots \\
\cdots\end{array}$ & $\begin{array}{r}140 \\
161 \\
97 \\
78 \\
64 \\
58 \\
86\end{array}$ & $\begin{array}{l}43(31) \\
72(45) \\
45(46) \\
42(54) \\
26(41) \\
25(43) \\
14(16)\end{array}$ & $\begin{array}{r}29(21) \\
62(39) \\
37(38) \\
31(40) \\
22(34) \\
21(36) \\
9(10)\end{array}$ & $\begin{array}{l}28.9 \\
35.6 \\
38.6 \\
34.9 \\
37 \cdot 6 \\
40 \cdot 8 \\
27 \cdot 8\end{array}$ & $\begin{array}{c}22(16) \\
40(25) \\
27(28) \\
23(29) \\
15(23) \\
18(31) \\
7(8)\end{array}$ & $\begin{array}{r}10(7) \\
14(9) \\
7(7) \\
7(9) \\
2(3) \\
4(7) \\
2(2)\end{array}$ \\
\hline $\begin{array}{l}\text { Day: } \\
\text { Monday } \\
\text { Wednesda } \\
\text { Thursday } \\
\text { Friday } \\
\text { Saturday }\end{array}$ & $\begin{array}{l}\ldots \\
\mathrm{lay} \\
\ldots \\
\ldots\end{array}$ & $\begin{array}{l}\cdots \\
\cdots \\
\cdots \\
\cdots\end{array}$ & $\begin{array}{l}\ldots \\
\cdots \\
\cdots\end{array}$ & $\begin{array}{r}42 \\
106 \\
126 \\
314 \\
114\end{array}$ & $\begin{array}{r}5(12) \\
29(27) \\
30(24) \\
154(49) \\
65(57)\end{array}$ & $\begin{array}{r}4(10) \\
25(24) \\
27(21) \\
121(39) \\
50(44)\end{array}$ & $\begin{array}{l}43 \cdot 8 \\
33 \cdot 4 \\
38 \cdot 6 \\
34 \cdot 9 \\
37 \cdot 1\end{array}$ & $\begin{array}{l}4(10) \\
13(12) \\
18(14) \\
89(29) \\
42(37)\end{array}$ & $\begin{array}{r}1(2) \\
0 \\
9(7) \\
27(9) \\
9(8)\end{array}$ \\
\hline \multicolumn{2}{|c|}{$\begin{array}{l}\text { Time: } \\
\text { Before } 8 \mathrm{pm} \\
8 \mathrm{pm}-10 \mathrm{pm} \\
\text { 10 pm-midnight } \\
\text { After midnight }\end{array}$} & $\begin{array}{l}\ldots \\
\cdots \\
\cdots\end{array}$ & $\begin{array}{l}\cdots \\
\cdots \\
\cdots\end{array}$ & $\begin{array}{l}206 \\
145 \\
182 \\
169\end{array}$ & $\begin{array}{r}42(20) \\
40(28) \\
82(45) \\
119(70)\end{array}$ & $\begin{array}{r}32(16) \\
35(24) \\
60(33) \\
100(59)\end{array}$ & $\begin{array}{l}35 \cdot 2 \\
42 \cdot 3 \\
35 \cdot 0 \\
34 \cdot 7\end{array}$ & $\begin{array}{l}23(11) \\
26(18) \\
49(27) \\
68(41)\end{array}$ & $\begin{array}{c}3(1) \\
6(4) \\
14(8) \\
23(14)\end{array}$ \\
\hline $\begin{array}{l}\text { Diagnosis: } \\
\text { Medical } \\
\text { Surgical } \\
\text { Self-poiso } \\
\text { Head inju } \\
\text { Minor tra } \\
\text { Major tra } \\
\text { Drunk } \\
\text { Psychiatti } \\
\text { Road traffic } \\
\text { Assault }\end{array}$ & $\begin{array}{l}. \\
\therefore \\
\text { oning } \\
\text { ury } \\
\text { auma } \\
\text { auma } \\
\text { tic distu } \\
\text { c accider } \\
\ldots\end{array}$ & $\begin{array}{l}\ldots \\
\because \\
\cdots \\
\ldots \\
\because \\
\text { rbances } \\
\ldots \\
. .\end{array}$ & $\begin{array}{l}\cdots \\
\cdots \\
\cdots \\
\cdots \\
\cdots \\
\cdots\end{array}$ & $\begin{array}{r}164 \\
71 \\
47 \\
37 \\
318 \\
45 \\
11 \\
9 \\
45 \\
29\end{array}$ & $\begin{array}{c}37(23) \\
11(15) \\
35(74) \\
20(54) \\
141(44) \\
24(53) \\
11(100) \\
4(44) \\
21(47) \\
25(86)\end{array}$ & $\begin{array}{r}23(14) \\
9(13) \\
24(51) \\
19(51) \\
117(37) \\
22(49) \\
10(91) \\
3(33) \\
17(38) \\
23(79)\end{array}$ & $\begin{array}{l}28 \cdot 9 \\
30 \cdot 4 \\
33 \cdot 6 \\
43 \cdot 4 \\
35 \cdot 2 \\
46 \cdot 0 \\
44 \cdot 7 \\
35 \cdot 8 \\
37 \cdot 3 \\
38 \cdot 2\end{array}$ & $\begin{array}{c}15(9) \\
2(3) \\
20(43) \\
15(41) \\
86(27) \\
16(36) \\
11(100) \\
3(33) \\
14(32) \\
16(55)\end{array}$ & $\begin{aligned} & 3(2) \\
& 2(3) \\
& 8(17) \\
& 3(8) \\
& 23(7) \\
& 6(13) \\
& 0 \\
& 1(11) \\
& 4(9) \\
& 4(14)\end{aligned}$ \\
\hline
\end{tabular}

considered that alcohol had contributed directly to attendance, and in $11(2 \%)$ patients' drunkenness was considered the only reason for their attendance. More men than women were affected by alcohol, as were a higher proportion of patients of lower social class and young to middle-aged adults (20-50 years; table I). The main circumstantial factor influencing the likelihood of alcohol use was time of attendance, with more of the patients attending late in the evening and at weekends being affected by alcohol. A positive breath-alcohol reading was less common in general medical and surgical patients than in cases of selfpoisoning, head injury, and major trauma. Although the prevalence of positive breath tests was high in patients who had been in road traffic accidents it was not substantially different from that found in patients with diagnoses such as minor trauma and psychiatric disturbances. Very high proportions of the patients who had been involved in assaults or had tried to poison themselves were affected by alcohol.

In patients with positive breath tests the mean concentrations of alcohol did not differ substantially among different categories. The greater differences were between men and women and between adults of working age and the very young and old (table I). The interaction of factors such as sex, class, age, time, and diagnosis in influencing the likelihood of a positive breath test was investigated by multiple logistic regression to test whether each factor had any effect for given levels of other factors (see figure). The results indicated that each of
TABLE II-Breath alcohol levels according to clinical and subjective assessment of alcohol use

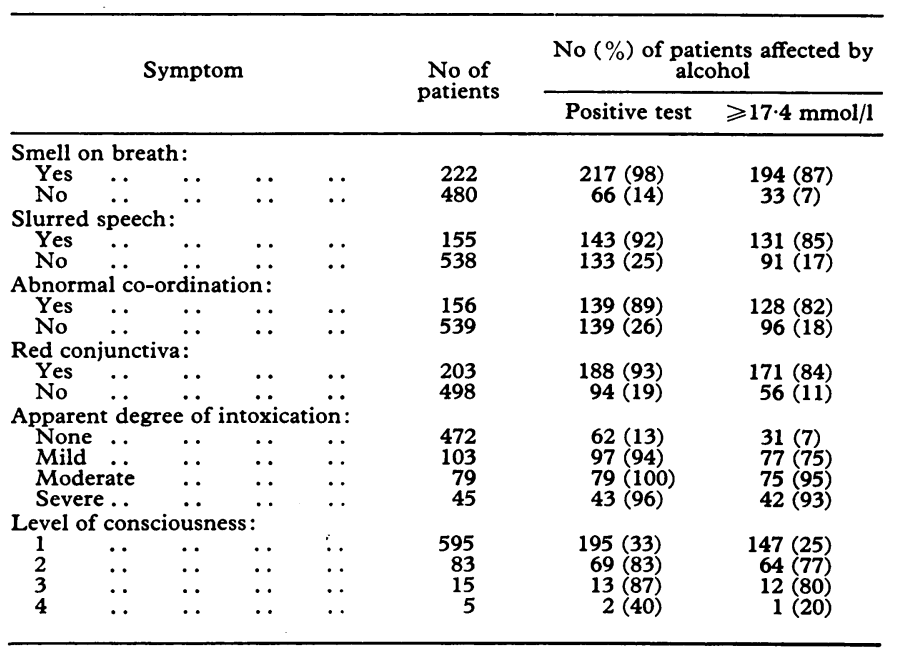


positive breath tests: in only $10 \%$ of cases was there disagreement, with an overall tendency for false-negative diagnosis (table II). The relation between the subjective (clinical examination) and objective (breath-alcohol analysis) measures of alcohol consumption was not strongly influenced by any of the patient characteristics, nor did the two doctors differ substantially in their ability to assess alcohol use.

One striking finding was the strong incidence of alcohol consumption in patients who were not fully conscious. Eighty-two per cent of patients whose level of consciousness was graded 2,3 , or 4 had a positive breathalcohol test and $75 \%$ had a breath-alcohol concentration of greater than $17.4 \mathrm{mmol} / \mathrm{l}$. Thus alcohol seemed to be a major contributing factor to a depressed level of consciousness since the proportion of semi-conscious or unconscious admissions from causes unrelated to alcohol was low.

\section{Discussion}

This study has shown that $40 \%$ of all patients attending an accident and emergency department in the evening had been drinking, and one-third of them may have been intoxicated (blood alcohol level greater than $17 \cdot 4 \mathrm{mmol} / \mathrm{l}){ }^{14}$ These findings confirm that alcohol use presents a major problem for emergency services and may be relevant for identifying alcoholism in hospital patients..$^{15}$ Alcohol abuse plays a major part in mortality and morbidity resulting from road traffic, industrial, and recreational accidents, ${ }^{16}$ and to be injured during a period of inebriation may be a strong indication that a patient has a drinking problem..$^{17}$ As in previous studies of alcohol use in casualty patients ${ }^{18-20}$ we cannot establish a causal relation between alcohol consumption and medical emergencies, but alcohol often appears to be associated with attendance at hospital. Patients presenting to accident and emergency services are therefore a suitable population to be screened for alcoholism. ${ }^{21}$

The frequent presence of alcohol abuse in the casualty patient raises important issues for the staffing, design, and treatment resources of accident and emergency services. Although many casualty departments possess a room for an intoxicated patient, ${ }^{22}$ there is generally no policy for assessing or following up patients with a drinking problem. ${ }^{23}$ One study of intoxicated patients attending an accident department concluded that $26 \%$ of patients admitted at night were intoxicated and that they were often not adequately managed6 ${ }^{23}$ Most were merely examined, sobered up, and discharged without follow-up. ${ }^{23}$ Such experience is similar to our own and shows a need for integrating alcoholism treatment resources into the accident and emergency services of general hospitals. Such decisions have important political as well as medical implications. ${ }^{24}$

The clinical diagnosis of alcohol intoxication is unreliable. ${ }^{6}$ In this study a false-negative diagnosis was made in $19 \%$ of intoxicated patients even though the examining doctors were motivated to detect the intoxicated patient. A test which gives an immediate blood alcohol reading may help to prevent misdiagnosis, delayed diagnosis, or potentially dangerous drugalcohol interactions. This study has shown that a pocket breathalcohol analysis instrument provides a rapid, non-invasive quantitative test that gives a useful indication of the blood alcohol concentration. In clinical practice many factors may change blood-breath correlations, ${ }^{13}$ but in most cases (except medicolegal) an approximate measure of severity of intoxication will suffice.

Further studies of alcohol abuse among patients attending accident and emergency departments at different times of day and in different places within the United Kingdom are warranted. If substantiated, our findings have major implications for the planning of acute health-care services.

The kind help of the staff of the accident and emergency department of the Royal Infirmary of Edinburgh is greatly appreciated. The following scientists and physicians kindly provided constructive criticism during the preparation of the manuscript: Dr M J Ashley, Department of Preventive Medicine and Biostatistics, University of Toronto; Professor Y Israel and Dr H A Skinner, Addiction Research Foundation, Toronto; Dr J C Duffy, Professor R E Kendall, Dr B
Ritson, Royal Edinburgh Hospital; and Professor R H Girdwood, Department of Therapeutics and Clinical Pharmacology, Edinburgh. Dr S Holt acknowledges support from Carnegie Trust for the Universities of Scotland. The breath-alcohol analysis instruments were kindly lent by Lion Laboratories, Cardiff.

\section{References}

${ }^{1}$ McCusker J, Cherubin CE, Zimberg S. Prevalence of alcoholism in general municipal hospital population. NY State 7 Med 1971;3:751-4.

${ }^{2}$ Moore RA. Prevalence of alcoholism in a community general hospital. Am F Psychiatry 1971;128:638-9.

3 Jarman CMB, Kellet JM. Alcoholism in the general hospital. Br Med $\mathcal{F}$ 1974 ;ii :469-72.

4 Edwards G. Patients with drinking problems. Br Med $\mathcal{F} 1968$;iv:435-7.

5 Wilkins RH. The hidden alcoholic in general practice. London: Elek Science, 1974.

${ }^{6}$ Bogen EJ. Drunkenness. F AMA 1927;89:1508-11.

7 Rutherford WH. Diagnosis of alcohol ingestion in mild head injuries. Lancet 1977 ; : $1021-3$.

${ }^{8}$ Patel AR, Roy M, Wilson GM. Self poisoning and alcohol. Lancet 1972; ii:1099-1102.

${ }^{9}$ Galbraith S. Misdiagnosis and delayed diagnosis in traumatic intracranial haematoma. $\mathrm{Br}$ Med $\mathcal{F} 1976$;i :438-9.

10 Welch TP, Wright BM. Alcohol and road accidents. Br Med $\mathcal{F} 1977$; i: $1032-7$.

11 Tennant FS. Use of a pocket size breath analyser in the detection and treatment of alcohol misuse. $\mathcal{F}$ Stud Alcohol 1979;40:518-21.

12 Office of Population Censuses and Sunweys. General Report. Part I. Definitions, Census 1971 England and Wales. London: HMSO, 1979.

13 Jones AW, Coldberg L. Evaluation of breath alcohol instruments. I In vitro experiments with alcometer pocket model. Forensic Science International 1978;12:1-9.

${ }^{14}$ Eastham RD. Biochemical values in clinical medicine, the results following pathological or physiological change. Bristol: John Wright and Sons 1975:3.

${ }^{15}$ Schmidt W, DeLint J. Causes of death of alcoholics. $Q \mathcal{F}$ Stud Alcohol $1972 ; 33: 171-85$.

${ }^{16}$ Chafetz ME. Alcoholism prevention and reality. $Q \mathcal{F}$ Stud Alcohol 1967; 28:345-48.

17 National Council on Alcoholism. (Criteria for the diagnosis of alcoholism). Am $\mathcal{f}$ Psychiatry 1972;129:127-35.

${ }^{18}$ Kirkpatrick JR, Taubenhaus LJ. Blood alcohol levels of home-accident patients. Qf Stud Alcohol 1967;28:734-7.

19 Wechsler H, Kasey EH, Thum D, Demone HW. Alcohol level and home accidents. Public Health Rep Washington 1969;84:1043-50.

${ }^{20}$ Honkanen R, Visuri T. Blood alcohol levels in a series of injured patients with special reference to accident and type of injury. Ann Chir Gynaecol 1976;65:287-94.

${ }^{21}$ Murray RM. In : Edwards G, et al, eds. Alcohol related disabilities. Geneva: World Health Organisation, 1977. Offset Publication No 32.

22 Anonymous. Accident and emergency services: design of departments. Br Med F 1979 ;ii : 1204-7.

${ }^{23}$ Glynn J, O'Neill F. Social intervention with intoxicated patients seen in an accident department. F Irish Med Ass 1974;67:40-2.

24 Kendell RE. Alcoholism: a medical or a political problem ? Br Med $\mathfrak{F}$ 1979 ;i:367-71.

ONE HUNDRED YEARS AGO In the Registrar-General's last quarterly return, the deaths of two alleged centenarians are recordedone at Tunbridge Wells and one at Hertford-the latter death being that of a female, whose age was said to be 103 years. Since the end of the quarter, a case of undoubted centenarianism has been recorded by $\operatorname{Dr} G M$ Bacon of the Cambridge County Asylum, who has taken pains to investigate the matter fully. Dr Bacon states that, on the 10th ultimo, a man named James Disborough completed his hundredth year. He is in fair health still, and of good memory and understanding, and states that he was born in 1780 , and baptised when about a year old. Dr Bacon has obtained from the Rector of Ashen, Essex, a copy of the entry in the parish register of the baptism on May 20th, 1781 . The other evidence is the tradition of the family as to the year of his birth, and his frequent statement that he was twenty in the year 1800 , and twenty-nine when he married in 1809 . He had seven children, thirty-two grandchildren, and fifty-nine great-grandchildren, and his eldest child is now nearly seventy. Dr Bacon states that: "On his hundredth anniversary, the four generations assembled in the old man's home, at Bradley, near Newmarket, to celebrate the event; and among several persons who called with a word of kindly congratulation on the occasion was the doctor, whose visit was at first resented by the old man, who considered himself far too well and hearty to require any medical attention." (British Medical fournal, 1880.) 